\title{
Ethanol as a potential mosquito sample storage medium for
}

\section{RNA preservation [version 1; peer review: 2 approved]}

\author{
Mirsha G. Torres, Allison M. Weakley, James D. Hibbert, Oscar D. Kirstein, \\ Gregory C. Lanzaro (iD, Yoosook Lee
}

Vector Genetics Laboratory, Department of Pathology, Microbiology, and Immunology, University of California Davis School of Veterinary Medicine, Davis, CA, 95616, USA

\begin{tabular}{l}
\hline V1 First published: 14 Aug 2019, 8:1431 \\
https://doi.org/10.12688/f1000research.20162.1 \\
Latest published: 14 Aug 2019, 8:1431 \\
https://doi.org/10.12688/f1000research.20162.1 \\
\hline
\end{tabular}

\section{Abstract}

Sample storage for downstream RNA analysis can be challenging in some field settings, especially where access to cryogenic materials or refrigeration/freezer facilities are limited. This has limited RNA-based studies on African malaria vectors collected in the field. We evaluated RNA quality after storing mosquito samples in three different sample preservation media over a 4-week period. Storing mosquito specimens in cold $\left(4^{\circ} \mathrm{C}\right)$ media significantly improved yields of intact RNA. Our results indicate commercially available products perform well in keeping RNA integrity as advertised. Moreover, absolute ethanol may be an economical alternative for sample preservation that can be utilized in some resource-limited settings.

Keywords

Sample storage, RNA preservation, field settings, mosquito, genetic analysis

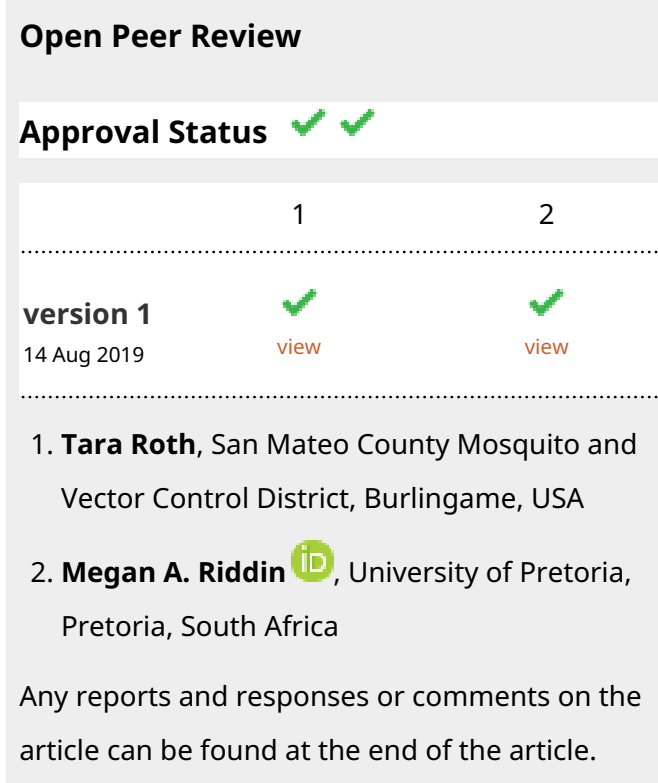

Corresponding author: Yoosook Lee (yoslee@ucdavis.edu)

Author roles: Torres MG: Data Curation, Formal Analysis, Investigation, Writing - Original Draft Preparation; Weakley AM:

Conceptualization, Investigation, Project Administration, Supervision, Writing - Review \& Editing; Hibbert JD: Data Curation, Validation;

Kirstein OD: Conceptualization, Investigation, Supervision, Writing - Review \& Editing; Lanzaro GC: Funding Acquisition, Writing -

Review \& Editing; Lee Y: Conceptualization, Formal Analysis, Supervision, Visualization, Writing - Original Draft Preparation, Writing -

Review \& Editing

Competing interests: No competing interests were disclosed.

Grant information: This work was supported by the University of California Irvine Malaria Initiative.

The funders had no role in study design, data collection and analysis, decision to publish, or preparation of the manuscript.

Copyright: @ 2019 Torres MG et al. This is an open access article distributed under the terms of the Creative Commons Attribution License, which permits unrestricted use, distribution, and reproduction in any medium, provided the original work is properly cited.

How to cite this article: Torres MG, Weakley AM, Hibbert JD et al. Ethanol as a potential mosquito sample storage medium for RNA preservation [version 1; peer review: 2 approved] F1000Research 2019, 8:1431 https://doi.org/10.12688/f1000research.20162.1

First published: 14 Aug 2019, 8:1431 https://doi.org/10.12688/f1000research.20162.1 


\section{Introduction}

Samples to be used for downstream RNA analysis (e.g. RNASeq) are typically preserved by snap-freezing using liquid nitrogen or dry ice and then stored at $-80^{\circ} \mathrm{C}$ until RNA extraction ${ }^{1,2}$. Several protocols have been published for preservation and extraction of genetic material from field collected samples ${ }^{3,4}$. Along with these protocols, there are products available to preserve nucleic acids from field collected specimens. These products include Allprotect Tissue Reagent (Qiagen, Hilden, Germany) and RNAlater (Thermo Fisher Scientific, Waltham, MA, USA). These reagents can stabilize tissue samples to maintain RNA content for one (RNALater) to six months (AllProtect) at mildly cold $\left(4^{\circ} \mathrm{C}\right)$ temperatures. The duration can be increased to over one year if samples are stored in colder $\left(-20^{\circ} \mathrm{C}\right)$ temperatures.

Optimal preservation of field collected samples to be used for gene expression studies require high quality nucleic acid, requiring preservation and stabilization of the RNA molecules. Unfortunately, the preservation of genetic material for expression studies based on field samples is difficult, and cryopreservation is often not possible. This is particularly applicable to field collections of Anopheles mosquitoes, which are the prime vector of malaria parasites ${ }^{6}$ and exist in remote areas of Africa.

\section{Methods}

Mosquito samples

A total of 54 laboratory-reared Anopheles coluzzii mosquitoes from the UC Davis Vector Genetics Laboratory insectarium were subjected to various sample preservation conditions, as listed in Table 1. Three different sample preservation solutions were tested: Allprotect Tissue Reagent (Qiagen, Hilden, Germany), RNAlater (Thermo Fisher Scientific, Waltham, MA, USA), and $100 \%$ ethanol. Each set of samples was maintained in one of the three preservation solutions and subjected to two different temperature settings: typical refrigeration temperature $\left(4^{\circ} \mathrm{C}\right)$ or at room temperature $\left(28^{\circ} \mathrm{C}\right)$. A total of nine mosquito samples were stored in each of the six conditions listed in Table 1 for 4 weeks prior to RNA extraction.

\section{RNA extraction}

Following a four-week sample preservation period, RNA was extracted from each mosquito sample using the Qiagen AllPrep DNA/RNA Mini Kit (Qiagen, Hilden, Germany) employing the manufacturer's protocol. The RNA concentration was

Table 1. Sample size per and specimen storage conditions.

\begin{tabular}{|c|c|c|}
\hline Storage Medium & Storage & Temperature \\
\hline$\left.{ }^{\circ} \mathbf{C}\right)$ & $\mathbf{N}$ \\
\hline AllProtect $^{\mathrm{TM}}$ & 4 & 9 \\
\hline AllProtect $^{\mathrm{TM}}$ & 28 & 9 \\
\hline RNALater $^{\mathrm{TM}}$ & 4 & 9 \\
\hline RNALater & & \\
\hline EtM & 28 & 9 \\
\hline Ethanol 100\% & 4 & 9 \\
\hline Ethanol 100\% & 28 & 9 \\
\hline
\end{tabular}

measured using a Qubit RNA High Sensitivity kit and Qubit 2.0 instrument (Thermo Fisher Scientific, Waltham, MA, USA) using the manufacturer's protocol. The RNA fragment size distribution was examined using the Agilent High Sensitivity RNA Analysis kit and TapeStation 4200 instrument (Agilent, Santa Clara, CA, USA), and the dominant peak size and proportion of long ( $>1000 \mathrm{bp}$ ) fragments were recorded. Typical RNA integrity number (RIN) which measures the $28 \mathrm{~S}$ and $18 \mathrm{~S}$ rRNA ratio was not used due to negligible $28 \mathrm{~S}$ peaks, which is typical for insect RNA extracts?

Data analysis

Mann-Whitney tests were conducted using the scipy module version $1.2 .0^{8}$ in the Jupyter notebook ${ }^{9}$ version 4.1. environment. Plots were generated using Matplotlib version 3.1.0 $0^{10}$.

\section{Results and Discussion}

Results for each sample are available as Underlying data ${ }^{11}$. Preservation conditions that resulted in the highest concentration of longer RNA fragments ( $>1000 \mathrm{bp}$ ) were considered to be best for downstream genetic analysis, as opposed to those resulting in degraded RNA (fragment size $<1000$ bp). As expected, storage at $4^{\circ} \mathrm{C}$ generally preserved RNA integrity better than $28^{\circ} \mathrm{C}$. There were no significant differences in total RNA concentration or dominant peak size between samples stored in AllProtect ${ }^{\mathrm{TM}}$ or RNALater ${ }^{\mathrm{TM}}$ at either storage temperature (Mann-Whitney test, P>0.05, Figure 1). Samples stored in absolute ethanol, however, showed a significant increase in RNA yield (Mann Whitney Test, $\mathrm{P}=0.0065$ ) and significant decrease in dominant peak size (Mann-Whitney test, $\mathrm{P}=0.00020$ ) when stored at $28^{\circ} \mathrm{C}$. We observed a significant reduction in long fragment $(>1000 \mathrm{bp}) \mathrm{RNA}$ in samples stored at $28^{\circ} \mathrm{C}$ than at $4^{\circ} \mathrm{C}$ regardless of the preservation solution (Mann-Whitney test, $\mathrm{a}<0.05)$. These results suggest, as expected, that higher temperatures accelerates tRNA degradation. Degradation was greater in absolute ethanol, decreasing the proportion of long (>1000bp) fragments from $74.1 \% \quad\left( \pm 5.6\right.$ STD) at $4^{\circ} \mathrm{C}$ to $16.9 \%( \pm 10.1 \mathrm{STD})$ at $28^{\circ} \mathrm{C}$. RNAlater and AllProtect ${ }^{\mathrm{TM}}$ maintained a $>40 \%$ content of RNA fragments of $\geq 1000 \mathrm{bp}$.

At $4^{\circ} \mathrm{C}$ no significant difference was observed in dominant RNA peak size (1600-1814 bp) and proportion of long (>1000bp) RNA fragments (62.2-74.9\%) among the three preservation media tested (Mann-Whitney test, $\mathrm{P}>0.05$ ). The only significant difference was a lower concentration of RNA in ethanol compared with the other preservation solutions (Mann-Whitney test, $\mathrm{P}<0.0081$ ).

Absolute ethanol did not preserve RNA integrity at $28^{\circ} \mathrm{C}$, with only $16.9 \%( \pm 10.1$ STD $)$ of RNA content composed of 1000 bp or longer fragments. However, the peak RNA fragment size for samples stored in absolute ethanol at $28^{\circ} \mathrm{C}$ was 869 bp $( \pm 73$ STD) showing little variation (Figure 1) yet similar concentrations as the other two preservation solutions. This quality may be sufficient to conduct downstream RNA analysis for real-time PCR or RNA-Seq.

Overall, samples stored in RNAlater ${ }^{\mathrm{TM}}$ or AllProtect ${ }^{\mathrm{TM}}$ at $4^{\circ} \mathrm{C}$ provide satisfactory preservation of RNA content from 


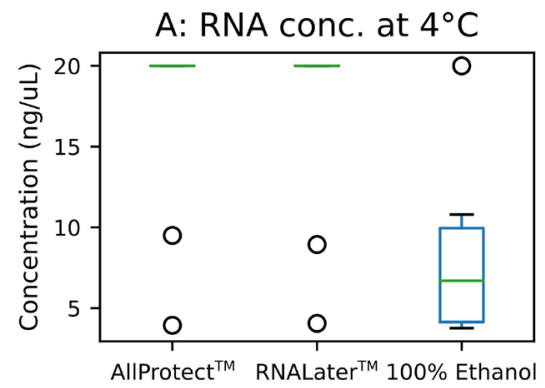

A: RNA conc. at $28^{\circ} \mathrm{C}$

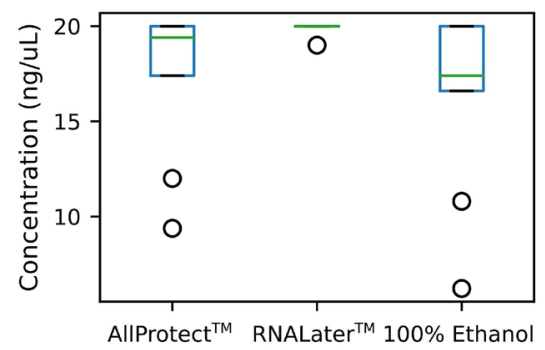

B: Dominant peak size at $4^{\circ} \mathrm{C}$

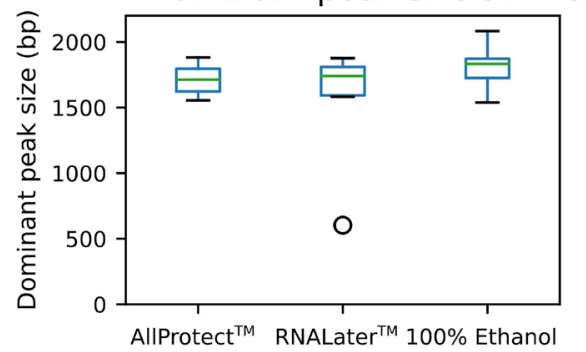

B: Dominant peak size at $28^{\circ} \mathrm{C}$

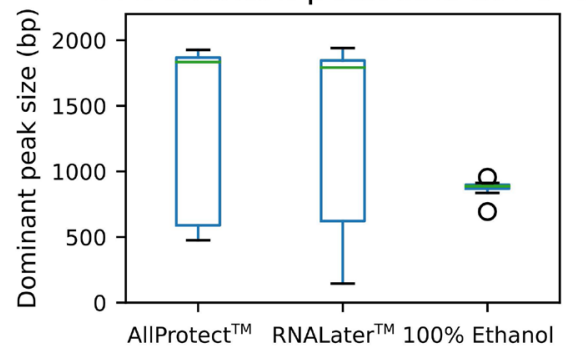

C: $\%(>1000 \mathrm{bp})$ at $4^{\circ} \mathrm{C}$

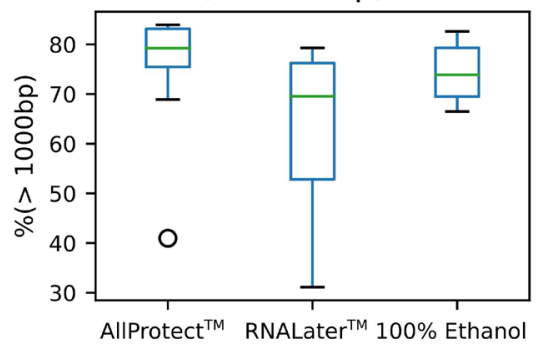

C: $\%(>1000 \mathrm{bp})$ at $28^{\circ} \mathrm{C}$

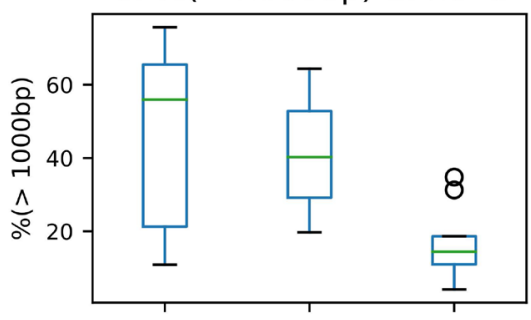

AllProtect $^{\mathrm{TM}}$ RNALater ${ }^{\mathrm{TM}} 100 \%$ Ethanol

Figure 1. Comparison of sample preservation media at two different temperature settings.

field collected samples after 4 weeks in storage. Absolute ethanol may provide an economical alternative in resourceconstrained field settings. Currently in the USA, AllProtect ${ }^{\mathrm{TM}}$ is available at $\sim \$ 6.5 / \mathrm{mL}$, RNAlater ${ }^{\mathrm{TM}}$ at $\$ 0.9-1.4 / \mathrm{mL}$, and 200 proof lab grade ethanol at $\$ 0.1-0.6 / \mathrm{mL}$. When stored at $4^{\circ} \mathrm{C}$, absolute ethanol may be a viable alternative to commercially available products. Although RNA stored in ethanol at $28^{\circ} \mathrm{C}$ will degrade faster, it nonetheless maintained fragment sizes over $800 \mathrm{bp}$ after 4 weeks in storage. Future evaluation of RNA quality utilizing real time PCR or RNA-seq may be necessary to elucidate whether ethanol is indeed an adequate sample preservation solution for RNA preservation. For practical applications, keeping specimens in a commercial RNA storage solution at $4^{\circ} \mathrm{C}$ maximizes maintenance of RNA integrity.

\section{Data availability}

Underlying data

Open Science Framework: Sample storage condition testing for RNA preservation. https://doi.org/10.17605/OSF.IO/BRNPV ${ }^{11}$.
This project contains data on RNA source, storage, concentration, dominant peak size and quality from each sample assessed in this study.

Data are available under the terms of the Creative Commons Attribution 4.0 International license (CC-BY 4.0).

\section{Grant information}

This work was supported by the University of California Irvine Malaria Initiative.

The funders had no role in study design, data collection and analysis, decision to publish, or preparation of the manuscript.

\section{Acknowledgement}

We thank Ms. Kendra Person (UC Davis) for providing samples used in this study.
1. Juneja P, Ariani CV, Ho YS, et al.: Exome and transcriptome sequencing of Aedes aegypti identifies a locus that confers resistance to Brugia malayi and alters the immune response. PLOS Pathog. 2015; 11(3): e1004765. PublMed Abstract | Publisher Full Text | Free Full Text

2. Zhao L, Alto BW, Shin D: Transcriptional Profile of Aedes aegypti Leucine-Rich Repeat Proteins in Response to Zika and Chikungunya Viruses. Int J Mol Sci.
2019; 20(3): pii: E615.

PubMed Abstract | Publisher Full Text | Free Full Text

3. Drakulovski P, Locatelli S, Butel C, et al:: Use of RNAlater as a preservation method for parasitic coprology studies in wild-living chimpanzees. Exp Parasitol. 2013; 135(2): 257-61.

PubMed Abstract | Publisher Full Text | Free Full Text 
4. Choo JM, Leong LE, Rogers GB: Sample storage conditions significantly influence faecal microbiome profiles. Sci Rep. 2015; 5: 16350. PubMed Abstract | Publisher Full Text | Free Full Text

5. Camacho-Sanchez M, Burraco P, Gomez-Mestre I, et al.: Preservation of RNA and DNA from mammal samples under field conditions. Mol Ecol Resour. 2013; 13(4): 663-73.

PubMed Abstract | Publisher Full Text

6. Manguin S: ANOPHELES MOSQUITOES - NEW INSIGHTS INTO MALARIA VECTORS Preface. Anopheles Mosquitoes - New Insights into Malaria Vectors. 2013; Xii-Xiii.

Publisher Full Text

7. Winnebeck EC, Millar CD, Warman GR: Why does insect RNA look degraded?
J Insect Sci. 2010; 10(1): 159.

PubMed Abstract | Publisher Full Text | Free Full Text

8. Jones E, Oliphant E, Peterson P, et al:: SciPy: Open Source Scientific Tools for Python. 2001.

Reference Source

9. Jupyter Team: Project Jupyter. 2015 Reference Source

10. Hunter JD: Matplotlib: A 2D graphics environment. Comput Sci Eng. 2007; 9(3): 90-5. Publisher Full Text

11. Lee Y: Sample storage condition testing for RNA preservation. 2019. http://www.doi.org/10.17605/OSF.IO/BRNPV 


\section{Open Peer Review}

\section{Current Peer Review Status:}

\section{Version 1}

Reviewer Report 27 August 2019

https://doi.org/10.5256/f1000research.22147.r52465

(C) 2019 Riddin M. This is an open access peer review report distributed under the terms of the Creative Commons Attribution License, which permits unrestricted use, distribution, and reproduction in any medium, provided the original work is properly cited.

\section{Megan A. Riddin}

UP Institute for Sustainable Malaria Control (UP ISMC), Faculty of Health Sciences, University of Pretoria, Pretoria, South Africa

This article addresses the efficacy of commercially available RNA preservation media and absolute ethanol at two temperatures, room temperature $\left(28^{\circ} \mathrm{C}\right)$ and cold $\left(4^{\circ} \mathrm{C}\right)$. The article focuses upon a critical topic that is the success of preservation of samples for downstream RNA analysis, particularly to find a reliable source in limited field source settings. The outcome of this study has direct application to a number of fields, including the study of malaria vectors which are often collected in preservation limited settings with a complete lack of freezer facilities for long periods.

This paper is a significant addition to the literature and has been addressed well. The selection of only a 4 week testing period is short, however, I feel the outcomes of this study can be immediately applied in a number of research fields, particularly research on mosquito disease vectors, as most field collections do not extend past such a period. By including absolute ethanol and a two RNA-preservative media options, this enables the covering of a cheaper and readily available option as well as other more stable, but more expensive and may be difficult to obtain, options for regions where snap-freezing is not an option.

\section{More specific comments:}

The authors covered the problem, objective and study highlights well in the abstract and state that absolute ethanol is a viable option in resource-limited settings.

I can highly appreciate that this was a direct study for the preservation of malaria vectors in the field which is predominantly in resource limited regions. It would complement the methods to include reasoning on selection of insectary-reared Anopheles coluzzii, 9 individuals and the 4 week period. This would be of interest to researchers who would replicate the methodology or adapt it for their sample and preservations needs. I commend the authors on including RNA concentration as well as fragment size distribution analysis, offering a comprehensive effect of the preservation method on RNA integrity. 
The results of the study are clearly and concisely described, and significance provided. The most important results are communicated and basis for conclusions are of high standard. The figures are understandable and visually descriptive. It is excellent that the authors further include an expense comparison for the appreciation of the use of absolute ethanol in funding and resource limited studies, as well as highlight the need for further evaluation of the preservation methods for real time PCR and RNA-seq.

Overall this is a worthy article which is a good addition to literature, and has direct application for RNA preservation.

Is the work clearly and accurately presented and does it cite the current literature? Yes

Is the study design appropriate and is the work technically sound?

Yes

Are sufficient details of methods and analysis provided to allow replication by others? Yes

If applicable, is the statistical analysis and its interpretation appropriate?

I cannot comment. A qualified statistician is required.

Are all the source data underlying the results available to ensure full reproducibility? Yes

Are the conclusions drawn adequately supported by the results?

Yes

Competing Interests: No competing interests were disclosed.

Reviewer Expertise: My research area is Medical Entomology, with focus on malaria vectors in southern Africa. My research pertains to mosquito vector epidemiology and control.

I confirm that I have read this submission and believe that I have an appropriate level of expertise to confirm that it is of an acceptable scientific standard.

Reviewer Report 27 August 2019

https://doi.org/10.5256/f1000research.22147.r52797

(C) 2019 Roth T. This is an open access peer review report distributed under the terms of the Creative Commons Attribution License, which permits unrestricted use, distribution, and reproduction in any medium, provided the original work is properly cited.

\section{Tara Roth}


San Mateo County Mosquito and Vector Control District, Burlingame, CA, USA

This is a useful methods paper to help clarify any misconceptions researchers might have about what is strictly necessary in order to preserve genomic specimens. I feel like this information could be highly useful for field researchers but also as information to help students just starting research projects.

Overall, I don't have many comments to make. The sample size is somewhat small but appears statistically valid. The one thing that would have been really nice to see is a comparison of the study findings to RNA degradation under ideal conditions $(-80)$ as well as with no preservation methods - just dry on the table.

Is the work clearly and accurately presented and does it cite the current literature? Yes

Is the study design appropriate and is the work technically sound?

Yes

Are sufficient details of methods and analysis provided to allow replication by others? Yes

If applicable, is the statistical analysis and its interpretation appropriate?

Yes

Are all the source data underlying the results available to ensure full reproducibility? Yes

Are the conclusions drawn adequately supported by the results?

Yes

Competing Interests: No competing interests were disclosed.

Reviewer Expertise: Infectious disease, real-time PCR, disease ecology, vector borne disease

I confirm that I have read this submission and believe that I have an appropriate level of expertise to confirm that it is of an acceptable scientific standard. 
The benefits of publishing with F1000Research:

- Your article is published within days, with no editorial bias

- You can publish traditional articles, null/negative results, case reports, data notes and more

- The peer review process is transparent and collaborative

- Your article is indexed in PubMed after passing peer review

- Dedicated customer support at every stage

For pre-submission enquiries, contact research@f1000.com 